\title{
Wakanda Forever
}

Racism is a system whose function is to confer privilege. That privilege has two main components, economic and psychic. Racism as a system is fundamentally reliant on binary thinking in order to build the symbolic meanings on which its material practices are erected. Historically and philosophically, racism is an implicit part of the well-intentioned liberalism which has crafted the individualized subject of Western psychology. As Perry (2018) has shown, the processes of the Enlightenment, together with the genocide and slavery that accompanied the colonialism which made modernity, needed a category of nonpersons in order to authorize and enrich the gendered and classed person who was a product of these historical forces. These processes of person production were as much economic and legal as they were psychological, showing once more the imbrication of all these forces.

Racism, of course, makes use of the construct of race to authorize itself. There is no scientific validity to the construct of race. There is only one, human race, although there are geographically regional genetic variants of humans. All the scientific and psychological work on race and putative racial differences in the nineteenth and twentieth centuries was research done on "something which was not there" (Richards, 2012, p. 19; 
see Posel, 2001; Richeson \& Sommers, 2016). Or, as Oluo (2019, pp. 11-12) puts it, race is "a lie told to justify a crime" (see also Kendi, 2016). The historical shaping of the idea of race helps to reveal it as a human political event, shaped by economic relations of power, colonial dynamics, law and citizenship rights, and so on. This will be explored in more detail below. The biological underpinnings of race thinking has shifted in the later twentieth and the twenty-first centuries to become more complexly cultural (Fernando, 2017), but the attachment to the idea of fundamental, defining differences, always constructed by hierarchical assumptions, remains in place and remains available to perpetuate oppressions.

Like gender difference, racial difference is embedded in and produced by human culture. Race and gender cannot really be understood in isolation from each other, as their meanings inform and rely on each other. Nor can class, location, ethnicity, ablebodiedness or religion be taken out of the meanings made of bodies that are raced and gendered in systems of modernity. Each identity category co-creates the others. Each has an interrelated material history that tends to pass itself off as natural and inevitable. And racial difference has been a specific focus of psychology, most problematically in its early contributions to scientific racism and eugenicist practices. In the late twentieth and in the twenty-first centuries, other psychologies have evolved with commitments to social justice and decolonial practices, which seek to counter the ways notions of racial difference have informed the work of early mainstream psychology, including in its early social and cultural variations. This later work is made possible because of the contributions of people other to psychology's developmentally white, Western, male and middle-class beginnings.

In this chapter, I offer a framework for understanding race and racism in the America I found when I arrived here as an immigrant a decade ago. Because I am a white South African who grew up under apartheid, the relations of racism between whites and Black people of African descent were most in focus for me. I have come to learn of the other flavors of racist oppression in which America specializes, against Latinx people, against indigenous Americans and against Asian Americans. The intersection of my theory of complicity and the complexities of racialized experiences is illustrated in this chapter via my engagement, as a white South 
African immigrant to America, with the film Black Panther. For this reason, this chapter will focus on the racism built by and from American slavery. I acknowledge that racisms extend and multiply, and have different historical trajectories and investments (Richards, 2012). My argument here, about how racial difference functions, can be applied to all symbolic uses of binary thinking imposed on human bodies.

Below, I offer more detail for a structural definition of racism, in order to continue to illustrate the connections between modernity, binary thinking and systems of oppression. I hope to show we can acknowledge the historical and ongoing operations of oppression, which work through creating binary differences, and nuance the ongoing subject positions such oppression produces. By now, in a world made impossibly complicated by the hybridizing, fracturing and commodifying realities produced by neocolonialism and neoliberalism, we need to recognize the extreme systemic inequalities within which the postmodern world resides, and also acknowledge that human being is not binary. We need to be able to think complicitously.

\section{Race}

The invention of modern notions of race and the racial difference it produces is rooted in historical practices of modernization, emerging capitalism and liberal individuality. It begins with slavery and proceeds through colonialism (Fernando, 2017; Kendi, 2016; Perry, 2018; Richards, 2012). Colonialism was not just a military enterprise. It was cultural and psychological too (Fanon, 2005; Wa Thiong'o, 1986; Wa Thiong'o, 1993), which postcolonial, liberation and decolonial psychologies continue to address (Adams et al., 2017; Fernández \& Gutierrez, 2020; Hook, 2012; Maldonado-Torres, 2017; Mignolo, 2011; Miller \& Miller, 2020).

As we saw in the last chapter, Perry (2018) shows how enslaved and colonized people were made to be the constituting others for emerging liberal capitalist modernity. Indigenous and enslaved people were legally and culturally conferred with nonpersonhood in order to help define the modern liberal subject. She also argues that public violence was enacted on the body of the racialized other long after Foucault (1977) denoted 
the end of public violence as a means of sovereign social control for white citizens. These very specifically racialized "mechanisms of domination" (Perry, 2018, p. 35) are part of what we are seeing in the ongoing violence publicly enacted by the state against Black and brown bodies on the streets of America today. This suggests the structural need modern American democracy has for the dehumanization of its constitutive others, and helps explain the apparent intractability of race as a necessary construct within a system built on the binary of self and other.

Teo (2005) adds to this historical picture the role of science as a system of classification, also developed through the Enlightenment and nineteenth century colonialism. The emerging discipline's obsession with grouping and measuring,

[W] as consequently applied to human populations... From a sociohistorical standpoint, the concept of "race" allowed for the justification of colonialism, domination, and slavery, because non-European groups (and certain European populations) were not just constructed as different, but also as inferior. (Teo 2005, pp. 155-6)

Here again are the invested hierarchical aspects that binary thinking brings to human differences, many of which are written on the body, for the purposes of psychic and economic gain.

Thus, as Perry (2018, p. 21) also shows, there have always been connections between abjected racialized bodies and bodies gendered female (see also Haraway, 1989; Richards, 2012):

The position of the nonperson is a fundamental supplementation of the idea of gender as produced by disciplinary power (essentialized concepts and rules for men and women) and the naturalization of binary gender categories that were, and continue to be, applied to citizenries.

The idea of racial difference requires binary gender difference as a conceptual underpinning. It is built on it and cannot be understood separate from it. Both make use of the body, and of regimes of inclusion and exclusion, normality and deviance, acceptability, policing and power (see Hook, 2012). By the same logic, sexuality and definitions of 
ablebodiedness are equally relevant to the construction of race (Cruz, 2016; McRuer, 2006; Stephens \& Boonzaier, 2020).

Since all of these identities are cultural constructs made from embodied differences, Rose (1998, p. 184) argues that the body is in fact "a body-regime" constructed by the linkages of "surfaces, forces, and energies." The body is not an absolute truth underlying experience, but a contingent effect of the experience we are allowed to have. The body is a "relationship." This is another view of human being as complicit: Our very bodies are formed in relation to each other and to the systems that make us as individuals and groups, and which we, in turn, continue to make, albeit differentially (this argument implicitly draws on Butler, 1999 too, and is applied to therapeutic modalities in Chap. 6).

Our raced bodies exist in relation to each other in an additional and very specific way. The centuries of horror inflicted on bodies and subjectivities raced not-white by Western culture have enabled the whiteness assembled on the bodies and in the behaviors of people invisibly raced white. The raced self/other relation on which the dominant modern mode of human subjectivity depends may be a construct, but it is a construct with devastating embodied force (see Hook, 2012; Salter \& Haugen, 2017).

To view a complicit way forward is to challenge the thinking on which white supremacy depends. And by white supremacy, I mean to invoke not only blatant white violence against racialized others, but the wellintentioned liberalism charted in the previous chapter, which enacts its own pernicious forms of epistemic and material violences on raced bodies. To continue to advocate for a complicit model for human being is not to attempt to deny the damage racism has done and continues to do, on subjectivities and bodies that may be co-constructed, but whose oppression and suffering are no less real for all that. Because of the ongoing effects of modern racism, it is sometimes necessary to talk of race as though it were real, in order to reach a point of being able to insist that it is not, while holding on to subjects and bodies formed by racial difference and respecting their experiences as such.

I acknowledge what race has been and continues to be in this country: one of the largest, most important, most profitable building blocks of America. After the initial colonization and the genocide of Native 
Americans it perpetrated, this country was built through slavery. This historical fact continues to affect everyone, and in specific ways, indigenous peoples and Black Americans. Jung (2015) understands racism as operating on a civic level, to define who may be part of the nation and its resources, and who should be excluded and exploited for the furtherance of those resources and those who benefit from them. This argument correlates with Perry's (2018) explication of the development of the American subject via colonialism and slavery. And George (2020) says that since America's very sense of its civilization is grounded in slavery, instead of civilization functioning to restrict instinctual aggression, as Freud suggested, in America's case, it facilitated it. The impulses that drove slavery are not past, "but a savagery essential to the modern" (George, 2020, p. 110).

The slave is used by the master, George (2020) shows, to make up for the master's subjective Lacanian lack. The slave is the jouissance of a modernity founded on racism and capitalism, and their unholy union. "Being was actively siphoned from the person of the slave in order to... grant the master access to whiteness as a master signifier of being" (George, 2020, p. 115). Being, here, indicates Lacan's formulation for the place of the subject (George, 2020, p. 111). George (2020) shows how the white American subject's sense of self was built on, at the expense of, the slave, providing a psychological correlative to Perry's (2018) legal and cultural history. This Lacanian symbolic structuring underpins American society, "founded... upon a brutal expression of base instincts that then root white identity in its signal notions of freedom and independence" (George, 2020, p. 117). One consequence is the importance of racial identity for African Americans, George (2020) says, which came to function as a place in which Black people could find their denied selves, in part through community. A result has been the development of a strategy "to fight racism with race" (ibid, p. 124).

To talk about this is to engage another complexity of the topic. We need to insist on the material and psychic consequences of this very specific history while remaining cognizant of one of its tropes, the "damaged negro" stereotype (for more on the history of this stereotype, see Richards, 2012, p. 172; Fernando, 2017, pp. 65-69; Griffith, 1977). Often well-intentioned white psychologists and sociologists, offering liberal accounts of the 
effects of oppression, created a version of Black family values and concomitant inner Black life and personality that offered new ways to reduce and stereotype Black people. Instead of nineteenth century biology-based arguments, the mid-twentieth century offered "cultural" reasons for Black inferiority (e.g., see the discussions about The Mark of Oppression by Kardiner and Ovesey [1951], or Moynihan's [1965] The Negro Family: The case for national action in Fernando, 2017 and Richards, 2012).

Psychology's twentieth century concern with the effects of racism tended to reinscribe the notion of the damaged oppressed Black person bearing the pathologizing "mark of oppression": culturally deprived, with low self-esteem, a destroyed and/or debased family structure, and no internal psychic resources to help himself, albeit through no fault of his own. Well-intentioned white psychologists helped underwrite this stereotype: "With friends like this ..." (Richards, 2012, p. 281). In America, Black psychologists have refuted this stereotype for as long as they have existed, since the 1930s (Guthrie 2004; Richards, 2012, chapter 11).

This is a complicated topic for a well-intentioned white woman to broach, as illustrated by Oluo's (2019, chapter 3) painfully funny account of her discussion about race with her white mother. I wish to properly acknowledge the complex process of surviving and speaking back to dehumanizing violence that is both actual and symbolic, without presenting victimhood as a constituting element of Black subjectivity under white supremacy, or reductively stereotyping Black people because we have a racist history of stereotyping Black people.

Binkley (2020) helps to theorize this problem by suggesting the raced subject is read through the double vision of generalized abnormalities assigned to a racialized type. Even with the mid-twentieth century shift of focus in psychology away from racial inferiority and toward racial oppression as a shaping factor on raced subjectivities, "the same assumptions concerning the radical alterity of the emotional and psychological lives of racial minorities remained intact," but this time cast as a cultural problem, not a biological truth (Binkley, 2020, p. 98). Racial categories are reorganized, but not fundamentally changed or addressed. Binkley (2020, p. 99) addresses the stereotype of Black emotionality, and especially Black rage, through this lens, which encompasses the racist idea of the "damaged negro." In current liberal psychologized contexts, Binkley 
(2020) says, the frightening specter of this angry, "damaged negro" is contained through white listening, a process whereby "the normal had to co-emotionalize with and listen to the abnormal... [which] served the ends of both criminalization and critique" (Binkley, 2020, pg. 100).

Binkley (2020) suggests also that, via the imperatives of neoliberalism, listening for the purposes of containment has become a corporate strategy for managing race. Binkley (2020) discusses the limits this model places on white empathy: whites must listen, but can never truly know the Black rage they must witness, and if they claim they can, they are revealing their failure of understanding, their as-yet-unredeemed racism. Hidden Black rage,

[B] ecomes precisely the second body it seeks to dispel... This is a second body whose eruptions bring powers of illumination that disrupt but also silently restore that other second body that is necessary for the racial contract to remain in place: the second body that constitutes whiteness itself. (Binkley, 2020, p. 104)

This is why, he says, institutionalized discussions about race largely fail to disrupt the status quo. He suggests that engaging with race through the emotions race gives us, each in our raced position, reinscribes race. Binary logic at work.

Binkley's (2020) attempts to account for the ongoing intractability of racist othering in well-intentioned spaces speak to the mess we are in. Many writers (e.g., Oluo, 2019) address how hard it is to talk about race in America today. DiAngelo (2018) engages in detail with the aspects of whiteness that defend against real conversations about the centrality of white privilege to structural racism, and the psychological fragility that is the consequence of inheriting a self made out of unearned privilege (see MacIntosh, 2008).

DiAngelo's book received national attention after the racial justice protests of 2020, following the police murder of George Floyd. A consequence has been a backlash against her attempts to hold white people accountable for the workings of white supremacy. One pertinent objection is similar to the problem we have tracked above, that her focus on the power of whiteness to perpetuate structural oppression demeans and 
disempowers Black people (McWhorter, 2020). Another is that she generalizes about white people (The Conversation, 2020). Trying to advocate for current accountability from white people (all white people, because the political, economic, educational, legal, psychological and cultural systems that have been built do create a starting point where personhood is assumed to be linked to whiteness, among other markers of human being), and acknowledge that oppression shapes lives, while also arguing that to be human is to be more than all these things, is a difficult business. Perhaps more than any other current issue, race makes clear the complicated inheritances of binary thinking woven into material practices.

In addition to the work of enslaved people themselves and those that came after, like W.E. du Bois, James Baldwin, Maya Angelou or Audre Lorde, there is a highly contemporary American literature that celebrates survival and documents the ongoing consequences of systemic racism for Black people, and for the society that continues to marginalize them. Here are a few examples: DeGruy (2005) offers an account of the effects of slavery on African American identities, providing psychological explanations for cultural adaptions. She offers the concept of Post-Traumatic Slave Syndrome to destigmatize survival responses to being Black in America. Boyd-Franklin (2006) writes about the psychology of Black families with a sensitive and nonhomogenizing lens. Brewster and Stephenson (2013) write about families, the education system and selfhood. Williams (2001) and Alexander (2011) penned stunning indictments on the legal system. Hardy $(2006,2008)$ has written and talked about racism in family therapy and as a developmental trauma. Tatum's (1997) "Why Are All the Black Kids Sitting Together in the Cafeteria?" and Other Conversations About Race remains a beautifully written and compelling account of the mechanisms and costs of racism. Adichie (2013) dealt with it through fiction. In the last few years, Coates (2015), Kendi (2016), Morris (2016), Dyson (2017), Menakem (2017), Cooper (2018) and Bryant (2020) have all spoken urgently about the ongoing experiences of black Americans, counting the ongoing costs of racism, emphasizing strength and resilience, and insisting on the structural elements of racism in America. 


\section{Racism}

Racism is not best defined as a psychological quality held by individuals. Psychological explanations miss the larger point of how and why racism operates. Racist structures do not only enable individuals to believe hateful things or behave hatefully. They also allow certain groups to act on this hatred, in ways that substantially and structurally affect others. Racist structures allow some to accrue privileges of all sorts, psychological and material, over others, by taking things away, psychological and material, from those others. Racist structures then justify and perpetuate that system of privilege. So while it may also be a personal attitude, racism operates and perpetuates structurally. As beneficiaries of the system, white people are implicated in racist oppression, whether we like it or not, and whether we think we mean it or not.

It is often said that the human brain cannot help but rely on group differences to make snap judgments (Hewstone et al., 2002; Richeson \& Sommers, 2016; Rippon, 2019). The arguments are not only neurobiological. A recent psychoanalytic article on otherness, for example, begins with the assertion, "There is an emotional/cultural need to define oneself in relation to otherness, manifesting clearly in racial, ethnic, national, religious, sexual, and gender identities" (Molofsky, 2019, p. 49. See also McWilliams 2020). And a recent social psychology-informed article, which explores the role of otherness to the idea of the citizen, suggests that human beings have always needed enemies in order to be able to define their friends (Mannarini \& Salvatore, 2020). The authors also make the point that neoliberal fragmentation has resulted in more intense cleaving to local and national identities that are therefore more reactive and more insular.

Current conditions may well have exacerbated binary thinking. But if it is inevitable that human beings will use groupthink to develop identities in a way that makes binary othering necessary, then we are very close to legitimizing racism. It is more historically and psychologically accurate to trace the ways that racial difference has been constructed and imposed on bodies, and to name the purpose of these activities: profit. Cushman (2019, pp. 41-43) also makes the point, following W.E.B. Dubois, that 
if we legitimize racism with a psychologized endorsement that humans neurobiologically cannot help but use binary thinking, then we miss the material, economic benefits to institutionalized oppression. Racism, a system which privileges some at the expense of others, is not an inevitable part of human nature. It is highly specific, invested, historical event. Binary thinking obscures this fact. It also, not coincidentally, thereby naturalizes the systems of thought that underpin colonially formed, capitalist-saturated modernity, with all its rules about who deserves to be on top and why: Darwinism, patriarchy, Freud's idea that it is human nature to dominate, and that domination is properly male and so on. Thinking of humans as complicit in the systems that structure us and which we, in turn, participate in and may sometimes alter accordingly, allows us a much more realistic and complex entry into how and why we oppress each other, how systems convince people to participate and collaborate, sometimes even in the process of resisting, and what the consequences are for human being in these systems, albeit with different people paying different prices.

Hook (2012, p. 4) offers the notion of the "psychopolitical" to fully account for the interactions of psychology and the complex interacting contextual forces which help to shape the psyche, and which are in turn shaped by psychological needs and pressures. In other words, to talk about racism we need more than a psychological vocabulary. We need to be able to combine insights about psyches with knowledge about systems of power, about historical forces and the events they shape, with understandings that are material as well as existential. We need, in other words, a psychology informed by knowledge from the humanities as well as the social sciences, because we need to be able to see how discourses shape what is humanly possible. Only then can we properly account for the historically specific, psychically invested, inscriptions of raced differences (and the gendered, classed, abled or disabled, sexually normal or perverse meanings they accompany) on human bodies and being.

Making sense of difference is a part of human being. But Western modernity's specific tactics are embedded in relations of power: economic, legal, nationalist, embodied, gendered and raced. They also make use of a morality of the good and the normal (which are sexually inflected); this is part of liberalism's inheritance. Binkley (2020, p. 96) suggests, via 
Foucault's ideas of normalization and the medicalization of the abnormal, that racism involves "a reading through" of the subjectivity of the raced other, to find the abnormality of the raced subject. He points out how scientific racism, which helped invent modern racial difference, used the idea of deviation from the implicitly white, European norm to classify racial others as inferior (see Teo 2005). Thus, again, racial difference has played a central role in the construction of modern relations of power, and racism is a product of the evolution of Western norms of personhood.

Hook (2007) explores how the processes of modern subjectification both and he and Rose (1998) detail can help us think about racism and racialized subjectivity. He (Hook 2007, p. 217) suggests we need to acknowledge that the processes of racialization which produce race and endorse racism demonstrate "affected subjectivity," that is, "a level of penetration and consolidation within subjects that is reducible neither to the terms of psychological explanation, nor to sociological critiques of determining social structures." Racism and the processes of racing it relies upon cannot be reduced to politics or economics or psychological gain. It saturates the structures into which we are born and which therefore shape us. It affects subjects on all complicit levels, interpersonally and intrapersonally. And it also requires access to the self/other binary in order to make its own hateful sense of things. If we are to dismantle racism and the structures that enable it, we have to be able to both acknowledge the profoundly personal implications of raced identity and ask for a new model which would undo the binary structure on which raced identity depends. Race structures this world, and is therefore central to human subjectivity and experience. It is also an artificial construct. In a real sense, it does not exist. As we have seen, it was brought into apparent being by systems of modernity, of which the psy disciplines are part.

\section{Race and Racism in and Through Psychology}

If the psy disciplines have been central to the emergence of modern, liberal democratic, states and subjects (and states of subjectivity), then they have also been central to the emergence of modern race and racism. Ideas about what constituted scientific method and proof, and the questions 
asked about human being via these formats, linked the emerging psy disciplines to emerging processes of racialization. Historically specific Western notions of scientific truth, liberal individuality, democratic governance and racial (and gender and sexual) difference are complicit in each other.

Evolutionary theory, which was a foundational colonial ideology, helped shaped the way psychology was used as it emerged as a discipline in the late nineteenth century. This impacted how apparent biological differences were used to construct differences in human being in order to create cultural, intellectual, moral and spiritual hierarchies. "The 'biologisation' of human diversity was thus consolidated; not only physical appearance but also temperament and culture reflected a people's innate evolutionary status" (Richards, 2012, p. 15). We have already explored the role of psychology in developing methods for producing individuality and the means for assessing these; Richards (2012, p. 22) makes the point that since psychometrics were developed in the service of eugenics, as a way to measure differences that were sought in order to be hierarchically ranked, "[s]tudying race differences is thus but an extension of the study of individual differences."

It is thus no surprise that psychology played a central role in the development of modern scientific racism. As is well-documented, psychology was enthusiastically involved in the development of theories of eugenics and of IQ testing which "proved" racial differences and white, European racial superiority (Fernando, 2017; Guthrie, 2004; Richards, 2012; Teo, 2005). And psychology's initial framing of empirical differences as biological set up the long-standing and extremely damaging "problematization" of Black people, in Teo's (2005, p. 173) term, in ways specific to how Blackness was raced (see Kendi, 2016; similar processes happened with other racialized groups). The effects on the practice of the psy disciplines have been recently charted in a series of essays published in response to the American cultural moment of 2019. This work explores the problems of well-intentioned whiteness, of structural racism and of the history of psychology in helping to shape these forces (Williams et al., 2019).

Richards (2012) says that psychology, as a discipline that emerged from America and Europe, could not not be racist and Western-centric (see also Fernando, 2017). He also suggests that there exists alongside the 
racism in psychology a "constant cycle" (Richards, 2012, p. 348) of antiracist intention that often fell short, being of its time and of its discipline. He asks that psychology's self-reflexive engagements with its constituting racist energies be acknowledged, along with the tools the discipline has developed to combat racism. For example, he argues that the process of engaging with the racism of the Race Psychology of the early twentieth century (see Fernando, 2017) helped make white psychologists aware of racism, and helped make racism a topic outside of psychology. To this we must insist that while we might be able to trace in psychology an academic trajectory from finding and ranking racial differences, to a concern with why people are racist and the effects of racism on people of color, the shortfalls cannot be overlooked in the name of good intentions. As a discourse born of white, European, male power and initially very committed to finding the scientific evidence for the rightness of that power, traditional psychology struggled, and arguably still struggles, to exceed its constitutive underpinnings. It has often ended up in the camp of wellintentioned whiteness that cannot see its own privilege and therefore perpetuates the structures of oppression it simultaneously disavows (Dovodio \& Casados, 2019; Richards, 2012; Salter \& Haugen, 2017).

Since the 1960s, psychology's constitutive others (Black people and people of color, the colonized, women, the neurodiverse, sex and gender perverts) have begun to speak back en mass, and from within. There are those newer psychological fields concerned with social, geographical, racial, economic and gender justice and their intersections, as more psychologists and psychologies from other places and othered identities have begun to establish voices in the field (e.g., Boonzaier \& van Niekerk, 2019; Collins et al., 2019; Ebersohn, 2019; Montero, 2017; Salter \& Haugen, 2017; Smith et al., 2013; Williams et al., 2019). More complex and important questions have become possible. Still in 2020, Bhatia (p. 263) was asserting that while we may acknowledge that, "Whiteness and white identity have played a dominant role in producing normative psychological knowledge in the U.S," the psy disciplines still do not acknowledge "the explicit ways in whiteness as privilege, power, norm, and an oppressive force acts as a dominant cultural norm and shapes the identities of both white people and non-white migrants [the focus of her article]." 
In part because of the ongoing unacknowledged operations of structural racism, "Unfortunately mainstream psychiatry and psychology have so far failed on the whole to fully take on board the insights offered by the progressive thinking that flooded the British and American scene at the end of the twentieth century" (Fernando, 2017, p. 85). Fernando (2017) details the regressive shift back toward racism in West in the twenty-first century. He attributes this to an inattention to structural matters in the previous century, as well as to racism's ability to shapeshift. He also specifically traces the rise of Islamophobia as a new incarnation of racism in America and Britain. He concludes that the psy disciplines may be too implicated in racist thinking and racist structures to be able to offer antiracist solutions in their current forms. And from a decolonial point of view, Miller and Miller (2020, p. 382) argue that psychology cannot be decolonized within the structures that exist, because the psy disciplines, colonialism, modernity, the state and individualism are all constitutive elements of the modern subject: "decolonization will take the end of the world, and... decolonization is the end of the world as we know it" because, "The very way in which we go about 'knowing' itself is entangled in colonial/modern ways of thinking that cannot but reproduce the violences at the core of their construction."

From this perspective, psychology's subaltern, by definition, still cannot speak. We need to approach the issue rather from a complicitous perspective than a binary one. Psychology, like English literature, can and has been changed in the hands of those whose enforced otherness helped to make both disciplines what they are. But a binary model, which locks in place oppressors and oppressed, cannot deliver any of us out of the self/other mode of being and knowing. This is another way the humanities, through postcolonial and cultural studies, can offer productive frames to psychological theories. But it does require relinquishing an exclusive commitment to scientific method, which cannot accommodate the philosophical complexity or the conceptual fluidity of complicity. We cannot operationalize or statistically demonstrate the complexities of mimicry and hybridity, the inevitably complicit agency of talking back in what started out as the master's language, of knowing and acting on what cannot be seen by systems of power. Nevertheless, all these ways of human being exist. 
I learned from studying postcolonial and neocolonial uses of and responses to Shakespeare, as an icon of universal humanity and cultural genius, that oppressed groups metabolize epistemic abuses and, even as they are changed by them, change them in turn. Oppressive forces destroy, but oppressed people also reclaim them, make them exceed their original intentions (Distiller, 2012a). People find all kinds of ways to fight back, ways that are also always complicit, as in the Hollywoodization and commodification of "Africa" in Black Panther that is also an act of highly overdue recognition and valuation by the systems that make us all.

\section{Complicities: Black Panther}

People of color continue to suffer from systemic oppression, and African Americans carry specific historical burdens in America today regardless of class affiliation. Black Americans cannot be sure of being safe as they walk down the street, or listen to music as they fill their cars with gas, or pray in their churches, or speak on their cellphones in their families' yards, or sleep in their own beds in their own apartments, free from a race-based denial of their very right to exist in their own country. Their citizenship rights are not assured in a place whose definition of human being began in racialized binary thinking. Perry (2018) has pointed out how the legal definition of Western personhood developed out of the deployment of the category of nonperson assigned to the slave, and Alexander (2011) has detailed the legacies of this system for Black and brown people in America today (see Williams, 1991). As I have been arguing, the implications run deep: into Western modes of individuality, linked to state and institutional belonging and the legal systems that allow or disable these; into capitalist imperatives to value and devaluation, of owning and ownership that confer human being and withhold human being; and in the complex constitutive connections between and among these systems. This legacy for Americans of African descent is what the 2018 Marvel superhero film Black Panther is speaking back to.

For those who have had no contact with popular culture in the last three years, here is a very brief summary of some key plot points: T'Challa (Chadwick Boseman) is the prince of the fictional African nation 
Wakanda, which has kept itself and its technological sophistication hidden from the world, pretending to be the expected African "third world country." T'Challa becomes the king and superhero Black Panther when his father, T'Chaka (John Kani), the king and the previous Black Panther, is killed. His antagonist in the film is an American special ops soldier nicknamed Killmonger (Michael B. Jordan), who is also his cousin, abandoned in Oakland as a child by T'Chaka. With the exception of a white CIA officer (Martin Freeman) who helps them, the other main characters are all powerful Black women, among them Shuri (Letitia Wright), T'Challa's genius sister, and Nakia (Lupita Nyong'o), his activist lover, who is a Wakandan spy in the outside world. In some really critical ways, Black Panther is a representational revolution, centering Black people as actors, characters, producers and makers of mainstream media. It depicts an Africanness that is deliberately created in opposition to the debased or demeaned version of neocolonial Africa which passes for Western knowledge of the continent, its people and its diaspora.

In 2014, Gay complained about the reductive and stereotyped depictions of Black experience in American movies. She asked for a cinema that went beyond the struggle narrative, that stopped fetishizing the broken Black body and reiterating Black victimhood as the only kind of subjectivity available to Black people in mainstream culture. With Black Panther, released four years later, I wager she got her wish. Directed by Ryan Coogler, released by Disney in February 2018, the movie was a revelation to the box office: a movie by and about Black people that made a whole lot of money. According to the Brookings Institute, Black Panther made $\$ 427$ million, placing it second only to The Avengers in terms of profits, and second only to Star Wars: The Force Awakens for opening profits (Sims, 2018; Sow \& Sy, 2018).

This was more than a commercial moment though, it was a moment of empowerment and visibility for Black people wherever Hollywood movies are sold:

The importance of seeing black people for the first time depicted in a major movie as kings, queens, inventors, and diplomats, rather than slaves, thugs, dealers and thieves, has given the movie a real-world political engagement not seen in other superhero films. The journalist Shaun King even went as 
far as to argue that it is a cultural phenomenon equal in importance to Dr. King's "I Have a Dream" speech and Rosa Parks refusing to give up her bus seat. (Faramelli, 2019, n.p.; see Faithful, 2018)

Offering a regal Black superhero to the world, Black Panther did something important for American culture and the subjects who inhabit it (González-Velázquez et al., 2020). As part of its centering of Black people, the film was as bold as it could be in addressing race and racism, given its conditions of production. It offered mainstream audiences a serious, unapologetic engagement with Black rage and Black power. It is remarkable that this conversation was even allowed to happen in a Disney blockbuster.

The film's exploration of possible responses to Western epistemologies of race and the centuries of colonialism thereby enabled focuses on Black experience and references African philosophies. Its central commitment is to exploring the politics of racial liberation (Newkirk, 2018; Orr, 2018). Faramelli (2019) sees Black Panther as resolving the dialectic it presents between different kinds of revolutionary theory, isolationism ("black sovereignty," represented by T'Challa) versus a radical engaged "black solidarity" (represented by Killmonger). It offers, he says, the option of a Sojan Thirdspace via the character of Nakia, not coincidentally a woman in a patriarchal culture (Wakanda is an absolute monarchy, with patriarchal lineage).

The Thirdspace is a hybrid space of dialogue and negotiation, not unlike the intersubjective third. For Faramelli (2019), this results in the film's embrace of a responsible, international form of Pan-Africanism, a rejection of Wakanda's traditional exceptionalism and an equal rejection of the cultural nationalism enabled by an essentializing, and therefore Manichean, negritude which "only reinforces the hegemony of colonial power." This last is evidenced in Killmonger's desire to create and rule a new world empire, won and held through military might.

Instead, T'Challa uses Wakanda's resources to begin a process of global outreach, starting in Oakland-implicitly a location which invokes the racialized struggles of African Americans, the birthplace of the real-life Black Panthers and the site of Killmonger's childhood trauma and radicalization. For Faramelli (2019), Black Panther rejects a business-as-usual 
liberalism for a new kind of radical engagement, led by Black women, as T'Challa decrees that Shuri and Nakia will run the Wakandan International Outreach Center. He concludes, "This Thirdspace position has the potential to create new spaces and transform the Oakland housing project where T'Chaka kills Killmonger's father into a space of liberation."

Not everyone loved, or agreed on, the film's message. Its heteronormativity has been critiqued (Meyer, 2020), as has its centering of African American needs to the exclusion of transnational and Islamic Africans (Alaoui \& Abdi, 2020). It has been faulted for its reiteration of African royalty as the model for African subjectivity, an objection made against other African American engagements with the continent (Rickford, 2020; Semphere, 2020). Zizek (2018), in his review of the film, calls it an "empty vessel containing antagonistic elements." He notes that the film's enthusiastic reception spanned the political spectrum. Black power advocates loved it, as did liberals who liked the "education and aid, not struggle" conclusion to the film's exploration of options for racial justice. And right-wing commentators found in the nationalist refrain "Wakanda Forever" a version of Trump's isolationist "America First" (see Faramelli, 2019; Varda \& Hahner, 2020).

There has been criticism from African writers of the film's valorization of an idealized Africa at the expense of engaging with the continent. While it offers "a rich embodiment of African culture,... [Black Panther] is surprisingly removed from the reality of today's African social issues and its politics" (Garside, 2018, p. 109; see Faramelli, 2019; Zizek, 2018). The film's use of other African countries as foils to Wakanda has been criticized as Western stereotyping, and its solution to the question of Wakanda's responsibility to Black people has been found to be, variously, and relatedly, neoliberal and Western development-oriented (Hanchey, 2020; Johnson \& Hoerl, 2020; Varda \& Hahner, 2020). Varda and Hahner (2020) argue that representational diversity alone is not enough to guarantee revolutionary representation, and Johnson and Hoerl (2020) accuse the film of maintaining whiteness despite its centering of Black bodies.

Despite also not being convinced that the ending was not endorsing a form of repurposed Western aid, albeit more community-minded and 
African-led (see Hanchey, 2020), I was profoundly moved by this film, and I felt profoundly ambivalent about my affective reaction to it. It is precisely an instantiation of complicity when I do not have language that is able to convey the full range and responsibility of what I mean: every time I see this film I am moved to tears by the vision of an independent, proud, empowered African nation that is greater than the West (and I know the problem with white women's tears, DiAngelo, 2018, and I am a white woman and I am also a colonially produced kind of African white woman); I ache for an Africa that has not been brutalized by colonialism and I know that to reduce the entire continent to a Western developmental discourse of abjection is not an accurate description of Africa or Africanness, and certainly does not see the humanity of Africans; as a white South African, my right to access Africanness is forever mediated by the racialized structures erected in my favor and from which I benefitted. But all this is who and what I am. As a white South African, I am the product and the beneficiary of colonialism and apartheid. And as a white, middle-class citizen of the global South, I sit at an angle at the table of neoliberalism and neocolonial cultural imperialism. As someone now living in America, I have all the privileges of American whiteness, and also stumble as an older immigrant through a place that does not value my origins, my experience or my age.

O'Loughlin (2020, p. 357) uses postcolonial notions of mourning to theorize the cost of the mimicry at work in trying, as in Irish immigrant, to be white in America. She invokes her "own autobiography, in which the acquisition of Whiteness is confounded by my origins in a colonized nation" to "suggest[...] that the encounter with the discourse of American Whiteness is troubled for those, like me, who, while we may pass as White-something Asian Americans and other persons of color cannot do-still experience a... splitting."

As a white South African, my whiteness is not partial, as O'Loughlin's Irishness renders her in a British context. Nevertheless, Black Panther confronted me head-on with the complicitous contradictions that make me. I too, experience a splitting. The difficulty speaking authentically from these multiple, fractured, contradictory positionalities is not only about my own struggle with my Good White Personhood. It is not only about my awareness of what it means to have grown up under apartheid 
and benefitted from it. It is also at least in part about the way identity functions in America as I have found it today. It seems to me that one of the rules of identity politics is that you cannot speak except of what you know from your own embodied experience, and only to others who are exactly like you. So where does this leave me? What am I authorized to speak about here?

Black Panther is a discussion between African Americans and continental black Africans. As Rickford (2020, n.p.) puts it, "African American imaginings of Africa often intermingle with.... intimate hopes and desires for Black life in the United States... [F] or African Americans,... Africa remains an abiding source of inspiration and identity." He writes of

[A] venerable African American tradition of crafting images of Africa that are designed to redeem the entire Black world... a retort to the contemptuous West and its condescending discourses of African danger, disease and degeneration... those tattered, colonialist tropes.

I felt a little like an eavesdropper, watching this movie, even as I also reveled in its reclamation of Africa from the typical, abjected Western depictions of the continent and its peoples, and as I felt myself a white African watching mainstream America claim a version of Africa as though it has just realized the continent has something to offer. I felt my fractures, my foldedness, my complicities.

The African aesthetic of Black Panther (see Faramelli, 2019), and some of its landscape, is deeply familiar to me, is in my bones and is embodied in me in complicated processes of subjectification and racialized domination. Some of it was filmed in my homeland. The cadence of the English of many of the African characters is one of the textures of my life. Some of the characters spoke isiXhosa, the hearing of which, in my current location, made me insider (South African) and outsider (white South African) and another kind of outsider (white person in America). I know also that it is my class-race-educational privilege that allows me to be a global citizen, to be in America legally, to afford the film. I also know that it is no uncomplicated feat for a white South African to claim a love of Africa and a relation to Africans, let alone a familiarity with a land and with people the exploitation of whom funded and nursed my very being. 
My childhood was structured by the incredibly complex and contradictory experiences of being surrounded, and care for, by Black women and men who were denied access to their own children and families so they could serve mine. The relationships were relationships of power that I could experience as relationships of connection. And yet they were also relationships of connection, however mediated and compromised. This cracked and damaged social, emotional, cultural reality is my South African version of the neocolonial world. It's fucked up, and it's also real and true. It is partial and compromised, and it is all I have. In Black Panther, I recognize South African cadences and artwork and languages and landscapes in ways that most Americans will not. And that is as much mine as the privilege and violence and horror that is my white Africanness. This is my embodied complicity.

As a student of early modern English literature, I had the chance to experience being treated as a subject of the colony, as an always inferior wannabe by the center of this particular power when I was a graduate student at Oxford University. One result of that experience was to shape my initial academic career around the question of colonial cultural politics, and of who might make what use of the cultural capital that is "Shakespeare." Since my field included South Africans and Shakespeare, I had repeated occasion to view, teach and write about the work of John Kani. His remarkable, revolutionary portrayal of Othello in apartheid South Africa, which I saw as a high school student at the time, is a key text for postcolonial Shakespearians (see Distiller, 2012b). The last production I saw before leaving South Africa starred the elder Kani as Caliban and his son, Atandwa, as a breathtaking Ariel, in The Tempest. Seeing them both in Black Panther (Atandwa Kani plays a younger version of King T'Chaka) felt personal to me. I feel proud of Atandwa Kani, as though he were my son's friend. I feel like I am watching a kinsman age when I feel grief at how old John Kani is looking. The passing of his years feels linked to the passing of mine, because of what we share in being South African as we share Shakespeare. There is a complicity at work here, which is comprised not only of the connections across colonialism and Englishness, but also by the fractures of South Africa's settler colonialism and apartheid histories. Kani and I are both of that web, and it connects us in powerful-power-full—ways. I know that my whiteness 
gave me a totally different experience of being South African to Kani's, and one that I had at the expense of Kani and his children. The challenge of speaking about any of this, here in America, is the challenge to navigate not only my history and the legacy of my late twentieth century (settler colonial, neocolonial) whiteness, but also the challenge of finding a speaking position within American identity politics in the present.

Black Panther's conversation with the aspects of Africa it uses to help set its scene is also a conversation about America's position in global networks of power. A constructed "Africa" is given valence, authority, legitimacy, as well as recognition, when it is valued by Hollywood in this way. This is both a victory and a collusion in, or co-option by, a system of valuation where worth is bestowed by a specific kind of circulation in a specific kind of public sphere, and authorized by commercial success. Thanks to Black Panther, "Africa" is now a successful brand. Here, too, is complicity.

Black Panther is overdue, and necessary, in the context of the ongoing devaluation of Africa and Black Africans, continental or diasporic. It is an important cultural corrective for America specifically and for the colonizing West. And it also indicates America's complicity in discourses of race and power transnationally. America's capitalist neocolonial power is part of what authorizes and conveys value on the version of Africanness that Black Panther so lovingly depicts. As I sit at the intersections of so many of these positions, as I try to hold my various complicities, I feel these splits as the only place any of us have from which to start trying to connect with each other.

In his beautiful exegesis of decoloniality, Mignolo (2011, p. 280) writes,

[F]or a white European body to think decolonially means to give; to give in a parallel way to the way a body of colour formed in colonial histories has to give if that body wants to inhabit postmodern and poststructuralist theories.

Mignolo has already explained why Western epistemologies cannot ever see the humanity of the West's others, and how the imbrications of colonialism and slavery with methods and institutions of knowledge creation mean that a new, delinked, decolonial way forward is the only 
option for what he calls Third World people. It is not what is enunciated that matters, he says, it is the always political fact of the enunciation that creates possibilities in the world. In this context, the white European body has to give up its liberal individuality, its good intention. It has to be willing to be changed, if it wants to enter the third space, beyond the either/ors of Western modernity, made possible by decoloniality. But what of the body that is not either white European or marked as colored by modernity? What of the white body born, because of modernity's systems of oppression, in the so-called Third World, into positions of power locally and of partial otherness globally? The complicities embodied thus, as I have been suggesting, need their own enunciative acts.

Humans unspeakably exceed the structural positions allocated to them by history, by systems of power, by tradition and by white supremacy and patriarchy. This place beyond language where something crucially human happens is detailed in Chap. 6. As much as we are trapped and determined by the structures in which we find ourselves, our capacity for complicity allows for sometimes unexpected, perhaps always partial, possibilities to find ourselves in new, unexpected, Thirdspace, intersubjective, terms. This is not to deny the brutalities of history, and it is to recognize the agency of those who survive it every day. It is also an attempt to understand the complicated, complicit work of racial justice that is done by Black Panther which is also the work of capitalism, and of American cultural colonialism, in the context of the possibilities and limits of identity politics.

A week after the movie's box-office-smashing opening, The Brookings Institute published, "Lessons from Marvel's Black Panther: Natural resource management and increased openness in Africa" (Sow \& Sy, 2018). The article draws lessons for "Africa," imagined as a singular place, from the movie, for example:

[W] hile oil and diamonds are not as versatile as vibranium [Wakanda's alien super-metal that is the source of its power] and cannot be used individually to promote the technological advancement of resource-rich African countries, there exists a space for the revenues they generate to be reinvested in technology and manufacturing, among other sectors. (Sow $\&$ Sy, 2018, n.p.) 
This rather slick correlation, between the power that the fictional vibranium conveyed on the fictional Wakanda and the power of oil and diamonds to bring money and technology to Africa, overlooks the brutal history of Western exploitation of African resources. The article notes that some countries in Africa, unlike Wakanda, tend to export their riches, and blames this process for "misaligned exchange rates, the decline of non-resource sectors, political authoritarianism, conflict, and economic inequality" (Sow \& Sy, 2018, n.p.). This is a gross oversimplification, to say the least.

Oil and diamonds - and ivory, and gold, resources plundered from The Congo and from South Africa, to name two specific additional examples-have not been underutilized by Africans because they did not think of developing those resources. They do not need the (American created) example of vibranium to remind them of what they might do by helping them to imagine the possibilities. And this easy vision of reinvested African resources pays no attention to neoliberal global economic systems which actively disempower Africa, or to the local and continental political aftermaths of colonialism.

The article concludes by hoping for more positive depictions of Africa in the movies (presumably American, since there is a thriving industry in Nigeria and a growing industry in South Africa). It calls into being through the existence of a fictional place the possibility that Africa's potential might be more fully respected and realized in the real world:

[F]ictional Wakanda provides an image of the prosperity and technological advancement, which awaits properly managed resource-rich countries. The subsequent technological proliferation and increase in global trade will hopefully be featured in the Black Panther sequel. (Sow \& Sy, 2018)

The representational power in imagining a different world, and thereby a different world order, does matter, as we have seen. But this cannot stand in for responsible mapping of why Wakanda is a fiction and not a reality. And feeling good about what we see on a Hollywood screen is not the same thing as actually engaging with what needs to change if we do want to see a more globally empowered African continent. 
Furthermore, a year later, Brookings returned to Black Panther in their "Africa in Focus" section in February of 2019, in an article entitled, "From Wakanda to reality: Building mutual prosperity between AfricanAmericans and Africa” (Signé \& Thomas-Greenfield, 2019). The authors called hopefully for the possibility of cultural heritage tourism for African Americans, which it contrasts to the holiday tourism for whites that it says comprises the bulk of the industry in Africa today. African Americans, say the authors, "may" be more interested in reconnecting with "Africa" than in "riding camels in the Sahara" like white tourists do. They suggest African American visitors use National Geographic to select places to visit (where, presumably, they will not see pictures of camels in the Sahara). The possibility of these new kinds of tourists opens up new commercial pathways, they suggest, and is a way for African Americans to "invest" in Africa's growth (Signé \& Thomas-Greenfield, 2019, n.p.).

"[D] uring the hype of 'Black Panther," the authors recount, "we both were giving talks on how to unlock Africa's potential." They continue:

Many of... the African-American professionals, community, and business leaders... asked us how they could help make Africa as successful as the imaginary Wakanda. In other words, where are the opportunities to develop mutually beneficial relations between Africa, African Americans, and the United States?

I value and respect the connections being made between Black Africans in different places across the globe. But I cannot help but notice the normalization of a Western, American model of economics that has everything to do with Black Panther, the brand. The authors are entrepreneurially riding the wave of possibility opened up for their careers by the movie's success; they are accurately noticing the ways global power relations currently work as they also seek to help empower "Africa." This empowerment, as I have been suggesting, is needed across spheres, from the material to the discursive. And yet the overarching value system that is accepted and continued by this entire exchange, by this conflation of the fictional and the real, by the assumption that a comic book can uplift the reductively constructed place "Africa," simplified into an idea by the (important) work of identity, all of this takes for granted and perpetuates 
American cultural dynamics that are very much part of the problem. Here is another example of complicity made visible by Black Panther. The cultural imperialism does not cancel out the representational empowerment. The connections between continental and diasporic Africans are not invalidated by the complex economic power dynamics at play. The yearning for African upliftment is not less important because there is also some Western-centric economic thinking at play here. It all works together to articulate some of the complexities and complicities of being human and being raced and being placed in this global time.

In this context, Newkirk's (2018) comments and question seem prescient, and to be speaking about complicity:

But the film will likely garner much of its earnings and generate much of its cachet from members of a mobile black middle class, centered largely in America, that have carved out some political and media prominence, both individually and as a group. Those viewers have rightly applauded the film for its incredible gains in representation, and will perhaps use it as a rallying cry for increasing diversity, often among their own ranks as a class. But Killmonger's question seems as pointed through the fourth wall toward them as it is to Wakanda: What will they do with the power they do have to make the world livable for those without it?

The question of how structurally oppressed groups of people have power differentially in relation to each other is a central one for the next chapter, which examines the dynamic between feminism, queer theory and transgender rights. In this example, too, I hope to show how binary thinking cannot serve and to suggest ways of working with psychotherapy clients who want or need to talk about their gender that opens up models of human being for us all.

\section{Works Cited}

Adams, G., Gómez, L. H., Kurtiş, T., Molina, L. E., \& Dobles, I. (2017). Notes on decolonizing psychology: From one Special Issue to another. South African Journal of Psychology, 47(4), 531-541. 
Adichie, C. N. (2013). Americanah. Random House.

Alaoui, F. Z. C., \& Abdi, S. (2020). Wakanda for everyone: An invitation to an African Muslim perspective of Black Panther. Review of Communication, 20(3), 229-235.

Alexander, M. (2011). The New Jim Crow: Mass incarceration in the age of colorblindness (Rev. ed.). New Press.

Binkley, S. (2020). Black rage and white listening: On the psychologization of racial emotionality. In D. M. Goodman, E. R. Severson, \& H. Macdonald (Eds.), Race, rage, and resistance: Philosophy, psychology, and the perils of individualism (pp. 90-107). Routledge.

Bhatia, S. (2020). Decolonizing psychology: Power, citizenship and identity. Psychoanalysis, Self and Context, 15(3), 257-266.

Boonzaier, F., \& van Niekerk, T. (Eds.). (2019). Decolonial feminist community psychology. Springer.

Boyd-Franklin, N. (2006). Black families in therapy: Understanding the African American experience (2nd ed.). Guildford.

Brewster, J., \& Stephenson, M. (2013). Promises kept: Raising black boys to succeed in school and in life. Spiegel \& Grau.

Bryant, H. (2020). Full dissidence: Notes from an uneven playing field. Beacon.

Butler, J. (1999). Gender trouble: Feminism and the subversion of identity. Routledge.

Coates, T. (2015). Between the world and me. Spiegel \& Grau.

Collins, L. H., Machizawa, S., \& Rice, J. K. (Eds.). (2019). Transnational psychology of women: Expanding international and intersectional approaches. American Psychological Association.

Cooper, B. (2018). Eloquentrage: A black feminist discovers her superpower. Picador. Cruz, A. (2016). The color of kink: Black women, BDSM, and pornography. New York University Press.

Cushman, P. (2019). Travels with the self: Interpreting psychology as cultural history. Routledge.

DeGruy, J. (2005). Post Traumatic Slave Syndrome: America's legacy of enduring injury and healing. Uptone Press.

DiAngelo, R. (2018). White fragility: Why it's so hard for white people to talk about racism. Beacon.

Distiller, N. (2012a). Shakespeare and the coconuts. Wits University Press.

Distiller, N. (2012b). Authentic protest, authentic Shakespeare, Authentic Africans: Performing Othello in South Africa. Comparative Drama, 46(3), 339-354. 
Dovodio, J. F., \& Casados, A. T. (2019). The science of clinician bias and (mis) behavior. In M. Williams, D. C. Rosen, \& J. W. Kanter (Eds.), Eliminating race-based mental health disparities (pp. 43-59). Context.

Dyson, M. E. (2017). Tears we cannot stop: A sermon to white America. St Martin's Press.

Ebersohn, L. (2019). Flocking together: An indigenous psychology theory of resilience in Southern Africa. Springer.

Faithful, G. (2018). Dark of the world, shine on us: The redemption of Blackness in Ryan Coogler's Black Panther. Religions, 9, 304.

Fanon, F. (2005). The Wretched of the Earth. Trans. R. Philcox. Grove.

Faramelli, A. (2019, September). Liberation on and off screen: Black Panther and Black Liberation Theory. Space, Place, and Identities Onscreen, 43(2). Retrieved October 13, 2020, from https://doi.org/10.3998/ fc. 13761232.0043 .202

Fernández, A. T., \& Gutierrez, M. C. (2020). Colonialism, gender and mental health in psychology: A view from Eastern Cuba. International Review of Psychiatry, 32(4), 340-347.

Fernando, S. (2017). Institutional racism in psychiatry and clinical psychology: Race matters in mental health. Palgrave Macmillan.

Foucault, M. (1977). Discipline and punish: The birth of the prison. Penguin.

Garside, D. (2018). Ryan Coogler's film Black Panther. South African Review of Sociology, 49(2), 107-110.

Gay, R. (2014). Bad Feminist, New York: Harper. is cited 1. 559.

George, S. (2020). Jouissance and discontent: A meeting of psychoanalysis, race, and American slavery. In D. M. Goodman, E. R. Severson, \& H. Macdonald (Eds.), Race, rage, and resistance: Philosophy, psychology, and the perils of individualism (pp. 108-131). Routledge.

González-Velázquez, C. A., Shackleford, K. E., Keller, L. N., \& Vinney, C. \&. Drake, L.M. (2020). Watching Black Panther with racially diverse youth: Relationships between film viewing, ethnicity, ethnic identity, empowerment, and wellbeing. Review of Communication, 20(3), 250-259.

Griffith, M. S. (1977). The influence of race on the psychotherapeutic relationship. Psychiatry, 40, 27-41.

Guthrie, R.V. (2nd, Ed.) (2004). Even the rat was white: A historical view of psychology. Boston: Pearson.

Hanchey, J. (2020). Decolonizing aid in Black Panther. Review of Communication, 20(3), 260-268.

Haraway, D. (1989). Primate visions: Gender, race, and nature in the world of modern science. Routledge. 
Hardy, K. (2006). Psychological residuals of slavery. DVD. Psychotherapy.net Hardy, K. (2008). Race, reality and relationships: Implications for the revisioning of family therapy. In M. McGoldrick \& K. V. Hardy (Eds.), Re-visioning family therapy: Race, culture, and gender in clinical practice (pp. 76-84). Guilford.

Hewstone, M., Rubin, M., \& Willis, H. (2002). Intergroup bias. Annual Review of Psychology, 53, 575-604.

Hook, D. (2007). Foucault, psychology, and the analytics of power. Palgrave.

Hook, D. (2012). A critical psychology of the postcolonial: The mind of apartheid. Psychology Press.

Johnson, J. L., \& Hoerl, K. (2020). Suppressing Black Power through Black Panther's neocolonial allegory. Review of Communication, 20(3), 269-277.

Jung, M. (2015). Beneath the surface of white supremacy: Denaturalizing U.S. racisms past and present. Stanford University Press.

Kendi, I. X. (2016). Stamped from the beginning: The definitive history of racist ideas in America. Bold Type Books.

MacIntosh, P. (2008). White privilege and male privilege: A personal account of coming to see correspondences through work in Women's Studies. In M. McGoldrick \& K. V. Hardy (Eds.), Re-visioning family therapy: Race, culture, and gender in clinical practice (pp. 238-249). Guilford.

Maldonado-Torres, M. (2017). Frantz Fanon and the decolonial turn in psychology: From modern/colonial methods to the decolonial attitude. South African Journal of Psychology, 47(4), 432-441.

Mannarini, T., \& Salvatore, S. (2020). The politicization of otherness and the privatization of the enemy: Cultural hinderances and assets for active citizenship. Human Affairs, 30, 86-95.

McRuer, R. (2006). Crip Theory: Cultural signs of queerness and disability. New York University Press.

McWhorter, J. (2020). The dehumanizing condescension of White Fragility. The Atlantic, July 15. Retrieved October 4, 2020, from https://www.theatlantic. com/ideas/archive/2020/07/dehumanizing-condescension-white-fragility/ 614146/?gclid=CjwKCAiAv4n9BRA9EiwA30WND-v_CdXagEBVzAogh4 D6J tOl1wiqwNdl6IEkM8blOts09B95ntoyRxoC8mcQAvD_ $\mathrm{BwE}$

McWilliams, N. (2020). Finding the other in the self. In D. M. Goodman, E. R. Severson, \& H. Macdonald (Eds.), Race, rage, and resistance: Philosophy, psychology, and the perils of individualism (pp. 180-197). Routledge.

Menakem, R. (2017). My grandmother's hands: Racialized trauma and the pathways to mending our hearts and bodies. Central Recovery Press. 
Meyer, M. (2020). Black Panther, queer erasure, and intersectional representation in popular culture. Review of Communication, 20(3), 236-243.

Mignolo, W. (2011). Geopolitics of sensing and knowing: On (de)coloniality, border thinking and epistemic disobedience. Postcolonial Studies, 14(3), 273-283.

Miller, L. L., \& Miller, M. J. (2020). Praxivist imaginaries of decolonization: Can the psy be decolonized in the world as we know it? Feminism \& Psychology, 30(3), 381-390.

Molofsky, M. (2019). Co-opting the body of the identified other: The hysterization of otherness in relation to self. Psychoanalytic Review, 106(1), 49-71.

Montero, M. (2017). Psychology of liberation revised (A critique of critique). In B. Gough (Ed.), The Palgrave handbook of critical social psychology (pp. 147-161). Palgrave Macmillan.

Morris, M. W. (2016). Pushout: The criminalization of black girls in schools. New Press.

Newkirk, V. R. (2018). The Provocation and power of Black Panther. The Atlantic, February 14. Retrieved October 28, 2020, from https://www.theatlantic.com/entertainment/archive/2018/02/the-provocation-andpower-of-black-panther/553226/

O'Loughlin, M. (2020). Whiteness and the psychoanalytic imagination. Contemporary Psychoanalysis, 56(2-3), 353-374.

Oluo, I. (2019). So you want to talk about race. Seal.

Orr, C. (2018). Black Panther is more than a superhero movie. The Atlantic, February 16. Retrieved October 28, 2020, from https://www.theatlantic. com/entertainment/archive/2018/02/black-panther-review/553508/

Perry, I. (2018). Vexy thing: On gender and liberation. Duke University Press.

Posel, D. (2001). Racial categorisations under apartheid and their afterlife. Transformation, 47, 50-74.

Richards, G. (2012). "Race", racism, and psychology: Towards a reflexive history (2nd ed.). Routledge.

Richeson, J. A., \& Sommers, S. R. (2016). Toward a social psychology of race and race relations for the twenty-first century. Annual Review of Psychology, 67, 439-463.

Rickford, R. (2020). The pitfalls of African consciousness. Africa is a country. Retrieved September 25, 2020, from https://africaisacountry.com/2020/09/ the-pitfalls-of-african-consciousness

Rippon, G. (2019). The Gendered Brain: The new neuroscience that shatters the myth of the female brain. Penguin.

Rose, N. (1998). Inventing our selves: Psychology, power and personhood. Cambridge University Press. 
Salter, P. S., \& Haugen, A. D. (2017). Critical race studies in psychology. In B. Gough (Ed.), The Palgrave handbook of critical social psychology (pp. 123-145). Palgrave Macmillan.

Semphere, T. (2020). Beyond African royalty. Africa is a country. Retrieved October 3, 2020, from https://africasacountry.com/2020/09/beyondafrican-royalty

Signé, L., \& Thomas-Greenfield, L. (2019). From Wakanda to reality: Building mutual prosperity between African-Americans and Africa. Brookings Insitute. Retrieved October 1, 2020, from https://www.brookings.edu/blog/africa-infocus/2019/02/14/from-wakanda-to-reality-building-stronger-relationsbetween-african-americans-and-africa/?utm_campaign=Brookings $\% 20$ Brief\&utm_source=hs_email\&utm_medium=email $\& u t m \_c o n-$ tent $=69969587$

Sims, D. (2018). The game-changing success of Black Panther. The Atlantic, February 20. Retrieved October 28, 2020, from https://www.theatlantic. com/entertainment/archive/2018/02/the-game-changing-success-ofblack-panther/553763/

Smith, C., Lobban, G., \& O’Loughlin, M. (Eds.). (2013). Psychodynamic psychotherapy in South Africa: Contexts, theories and applications. Wits University Press.

Sow, M., \& Sy, A. (2018). Lessons from Marvel's Black Panther: Natural resource management and increased openness in Africa. Brookings Institute, February 23. Retrieved May 2, 2019, from https://www.brookings.edu/blog/africa-infocus/2018/02/23/lessons-from-marvels-black-panther-natural-resourcemanagement-and-regional-collaboration-in-africa/

Stephens, A., \& Boonzaier, F. (2020). Black lesbian women in South Africa: Citizenship and the coloniality of power. Feminism \& Psychology, 30(3), 324-342.

Tatum, B. D. (1997). "Why are all the black kids sitting together in the cafeteria?" and other conversations about race. Basic.

Teo, T. (2005). The critique of psychology: From Kant to postcolonial theory. New York: Springer.

The Conversation. (2020). Robin DiAngelo's White Fragility ignores the differences within whiteness. August 27. Retrieved October 4, 2020, from https:// theconversation.com/robin-diangelos-white-fragility-ignores-the-differenceswithin-whiteness-143728

Varda, S. J., \& Hahner, L. A. (2020). Black Panther and the alt-right: Networks of racial ideology. Critical Studies in Media Communication, 37(2), 133-147. 
Wa Thiong'o, N. (1986). Decolonizing the mind: The politics of language in African literature. James Currey.

Wa Thiong'o, N. (1993). Moving the centre: The struggle for cultural freedoms. James Currey.

Williams, P. (1991). The alchemy of race and rights: Diary of a law professor. Harvard University Press.

Williams, M., Rosen, D. C., \& Kanter, J. W. (Eds.). (2019). Eliminating racebased mental health disparities. Context.

Zizek, S. (2018). Quasi duo fantasies: A Straussian reading of "Black Panther." Los Angeles Review of Books, March 3. Retrieved October 27, 2020, from https://www.lareviewofbooks.org/article/quasi-duo-fantasias-straussianreading-black-panther\#!

Open Access This chapter is licensed under the terms of the Creative Commons Attribution 4.0 International License (http://creativecommons.org/licenses/ by/4.0/), which permits use, sharing, adaptation, distribution and reproduction in any medium or format, as long as you give appropriate credit to the original author(s) and the source, provide a link to the Creative Commons licence and indicate if changes were made.

The images or other third party material in this chapter are included in the chapter's Creative Commons licence, unless indicated otherwise in a credit line to the material. If material is not included in the chapter's Creative Commons licence and your intended use is not permitted by statutory regulation or exceeds the permitted use, you will need to obtain permission directly from the copyright holder.

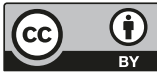

